\title{
It's not just the lungs: COVID-19 and the misty mesentery sign
}

\author{
Chiara Giraudo $^{1}$, Giulia Fichera ${ }^{1}$, Raffaella Motta ${ }^{1}$, Gabriella Guarnieri ${ }^{2}$, Mario Plebani ${ }^{3}$, Michela Pelloso ${ }^{3}$, \\ Andrea Vianello ${ }^{2}$, Roberto Stramare ${ }^{1}$
}

${ }^{1}$ Department of Medicine - DIMED, University of Padova, Padova, Italy; ${ }^{2}$ Respiratory Pathophysiology Division, Department of Cardio-Thoracic, Vascular Sciences and Public Health, University of Padova, Padova, Italy; ${ }^{3}$ Department of Laboratory Medicine, Department of Medicine-DIMED, University of Padova, Padova, Italy

Correspondence to: Chiara Giraudo, MD, PhD. Institute of Radiology, Department of Medicine - DIMED, Padova University, Via Giustiniani 2, 35100, Padova, Italy. Email: chiara.giraudo@unipd.it.

Submitted Dec 30, 2020. Accepted for publication Jan 22, 2021.

doi: 10.21037/qims-20-1406

View this article at: http://dx.doi.org/10.21037/qims-20-1406

Since the beginning of the current Severe acute respiratory syndrome coronavirus 2 (SARS-CoV-2) pandemic, numerous studies demonstrated the systemic effect of COVID-19 by showing the involvement of different organs and anatomical areas such as the brain and the abdomen $(1,2)$. In line with this evidence, in our clinical practice, we noticed the occurrence of the misty mesentery sign (i.e., increased attenuation of the mesenteric fat) in the upper abdomen of COVID-19 patients who underwent chest computed tomography (CT) (3).

Thus, we retrospectively assessed the first chest CT, including part of the upper abdomen, of all patients affected by COVID-19 (i.e., positive at Reverse transcription polymerase chain reaction (RT-PCR)) referring to our tertiary center from March to September 2020. We collected demographics, first-line clinical and laboratory information (i.e., fever, gastrointestinal symptoms, white and red blood cell count, levels of hemoglobin and C-reactive protein (CRP)). We applied the Student's $t$-test and the Fisher's exact test, for continuous and categorical variables, to evaluate potential differences between patients with and without the misty mesentery sign. All statistical analyses were performed with SPSS (IBM SPSS Statistics v.26, IBM Armonk, NY, USA) (level of significance $\mathrm{P}<0.05$ ).

Fifteen $(13.3 \%)$ out of the 113 patients matching the inclusion criteria ( 31 females; mean age \pm standard deviation, $65.1 \pm 14.4$ years) showed an area of high density within the mesenteric fat associated with enlarged lymph nodes (Figure 1). Chest CT was performed on average $24.4 \pm 17.3$ days after hospital admission. Five patients died, all without the misty mesentery sign. Four out of the 15 patients with misty mesentery were obese. Other four patients, all without misty mesentery, had a clinical history of cancer. Regarding the clinical and laboratory findings, patients with misty mesentery showed only significantly higher CRP values $(117.5 \pm 95$ vs. $56 \pm 65 \mathrm{mg} / \mathrm{L}, \mathrm{P}=0.029$; Table 1).

The misty mesentery sign can occur in various conditions, like trauma, abdominal cancer, and infections (3). Regarding the latter, Roginsky et al. described it in one patient with Vibrio Cholerae but it was not previously reported in COVID-19 patients (4). The fact that in our cohort the misty mesentery sign was associated with higher levels of CRP lets us assume that the hyperinflammation due to COVID-19 may be the cause (5). On the other hand, we cannot exclude that it might be part of the spectrum of abdominal findings caused by vascular changes previously described in the recent literature $(2,6)$. Unfortunately, we could not assess the patency of the abdominal vessels since most of the patients underwent unenhanced CT scans. Further radiological research on the vascular involvement in COVID-19 patients is certainly necessary.

This preliminary evaluation has several limitations. First, there is a lack of longitudinal data because many patients did not perform a follow-up CT or the upper abdomen was not included. Therefore, the prospective assessment of COVID-19 patients and a standardized protocol including the upper abdomen, possibly on patients selected according to the CRP levels, may provide new insights. Second, we could not fully evaluate the prognostic role of the misty 

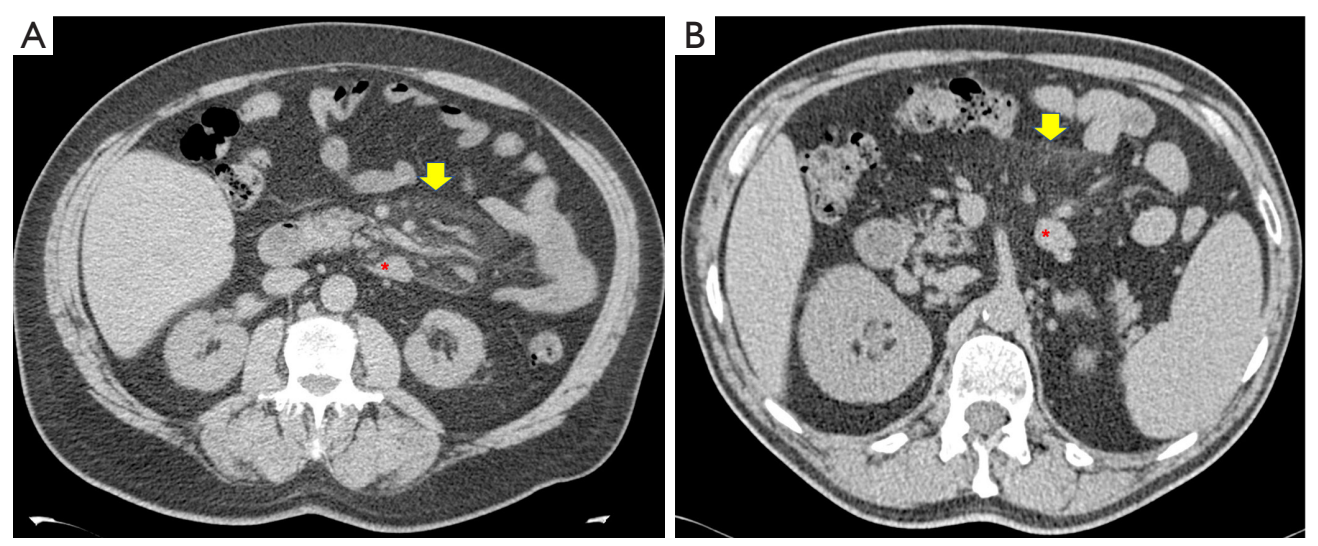

Figure 1 Computed tomography (CT) images showing the misty mesentery sign in two COVID-19 patients. In particular, axial CT of the upper abdomen of two male patients of 70 (A) and 61 years old (B) showing hyperdense mesenteric fat (i.e., misty mesentery sign; yellow arrows) with enlarged lymph nodes (red asterisks).

Table 1 Comparison of the clinical and laboratory findings between patients with and without the misty mesentery sign at computed tomography

\begin{tabular}{lccc}
\hline & Misty mesentery & No misty mesentery & P \\
\hline Gender $^{\mathrm{a}}$ (female/male) & $3 / 12$ & $28 / 70$ & 0.757 \\
Age $^{\mathrm{b}}$ (years) & $66.5 \pm 11$ & $64.9 \pm 15$ & 0.609 \\
Fever $^{\mathrm{a}}$ (yes/no) & $13 / 2$ & $94 / 4$ & 0.180 \\
Gastrointestinal symptoms $^{\mathrm{a}}$ (yes/no) & $2 / 13$ & $11 / 87$ & 0.683 \\
Hemoglobin $^{\mathrm{b}}$ (g/L) & $12.5 \pm 1.5$ & $13.2 \pm 2$ & 0.136 \\
Red blood cells count $^{\mathrm{b}}\left(\times 10^{12} / \mathrm{L}\right)$ & $4.4 \pm 0.6$ & $4.6 \pm 0.6$ & 0.447 \\
White blood cells count $^{\mathrm{b}}\left(\times 10^{9} / \mathrm{L}\right)$ & $6.7 \pm 3.3$ & $7.1 \pm 3.6$ & 0.694 \\
C-reactive protein $^{\mathrm{b}}(\mathrm{mg} / \mathrm{L})$ & $117.5 \pm 95$ & $56 \pm 65$ & 0.029 \\
\hline
\end{tabular}

a, Fisher's exact test; ${ }^{b}$, Student's $t$-test; applied level of significance $\mathrm{P}<0.05 . \mathrm{SD}$, standard deviation.

mesentery because at the beginning of the pandemic CT scans were rarely performed on critical patients for safety reasons related to patients' transfer. Studies on a larger population with a more balanced distribution of the outcome should be performed.

In conclusion, according to our preliminary experience, patients with COVID-19 can show the misty mesentery sign which seems to be associated with high levels of inflammation. Further research is needed to fully explore the role of this finding in the global assessment of patients with COVID-19.

\section{Acknowledgments}

Funding: This study did not receive any specific grant from any funding agency in the public, commercial, or not-for- profit sectors.

\section{Footnote}

Provenance and Peer Review: This article was a standard submission to the journal. The article did not undergo external peer review.

Conflicts of Interest: All authors have completed the ICMJE uniform disclosure form (available at http://dx.doi. org/10.21037/qims-20-1406). The authors have no conflicts of interest to declare.

Open Access Statement: This is an Open Access article distributed in accordance with the Creative Commons Attribution-NonCommercial-NoDerivs 4.0 International 
License (CC BY-NC-ND 4.0), which permits the noncommercial replication and distribution of the article with the strict proviso that no changes or edits are made and the original work is properly cited (including links to both the formal publication through the relevant DOI and the license). See: https://creativecommons.org/licenses/by-nc-nd/4.0/.

\section{References}

1. Kremer S, Lersy F, de Sèze J, Ferré JC, Maamar A, Carsin-Nicol B, Collange O, Bonneville F, Adam G, Martin-Blondel G, Rafiq M, Geeraerts T, Delamarre L, Grand S, Krainik A, Caillard S, Constans JM, Metanbou S, Heintz A, Helms J, Schenck M, Lefèbvre N, Boutet C, Fabre X, Forestier G, de Beaurepaire I, Bornet G, Lacalm A, Oesterlé H, Bolognini F, Messié J, Hmeydia G, Benzakoun J, Oppenheim C, Bapst B, Megdiche I, Henry Feugeas MC, Khalil A, Gaudemer A, Jager L, Nesser P, Talla Mba Y, Hemmert C, Feuerstein P, Sebag N, Carré S, Alleg M, Lecocq C, Schmitt E, Anxionnat R, Zhu F, Comby PO, Ricolfi F, Thouant P, Desal H, Boulouis G, Berge J, Kazémi A, Pyatigorskaya N, Lecler A, Saleme S, Edjlali-Goujon M, Kerleroux B, Zorn PE, Matthieu M, Baloglu S, Ardellier FD, Willaume T, Brisset JC, Boulay C, Mutschler V, Hansmann Y, Mertes PM, Schneider F, Fafi-Kremer S, Ohana M, Meziani F, David JS, Meyer $\mathrm{N}$, Anheim M, Cotton F. Brain MRI Findings in Severe COVID-19: A Retrospective Observational Study. Radiology 2020;297:E242-51.

Cite this article as: Giraudo C, Fichera G, Motta R, Guarnieri G, Plebani M, Pelloso M, Vianello A, Stramare R. It's not just the lungs: COVID-19 and the misty mesentery sign. Quant Imaging Med Surg 2021;11(5):2201-2203. doi: 10.21037/qims20-1406
2. Bhayana R, Som A, Li MD, Carey DE, Anderson MA, Blake MA, Catalano O, Gee MS, Hahn PF, Harisinghani M, Kilcoyne A, Lee SI, Mojtahed A, Pandharipande PV, Pierce TT, Rosman DA, Saini S, Samir AE, Simeone JF, Gervais DA, Velmahos G, Misdraji J, Kambadakone A. Abdominal Imaging Findings in COVID-19: Preliminary Observations. Radiology 2020;297:E207-15.

3. McLaughlin PD, Filippone A, Maher MM. The "misty mesentery": mesenteric panniculitis and its mimics. AJR Am J Roentgenol 2013;200:W116-23.

4. Roginsky G, Mazulis A, Ecanow JS, Ehrenpreis ED. Mesenteric Panniculitis Associated With Vibrio cholerae Infection. ACG Case Rep J 2015;3:39-41.

5. Manson JJ, Crooks C, Naja M, Ledlie A, Goulden B, Liddle T, Khan E, Mehta P, Martin-Gutierrez L, Waddington KE, Robinson GA, Ribeiro Santos L, McLoughlin E, Snell A, Adeney C, Schim van der Loeff I, Baker KF, Duncan CJA, Hanrath AT, Lendrem BC, De Soyza A, Peng J, J'Bari H, Greenwood M, Hawkins E, Peckham H, Marks M, Rampling T, Luintel A, Williams B, Brown M, Singer M, West J, Jury EC, Collin M, Tattersall RS. COVID-19-associated hyperinflammation and escalation of patient care: a retrospective longitudinal cohort study. Lancet Rheumatol 2020;2:e594-e602.

6. Guo Y, Hu X, Yu F, Chen J, Zheng W, Liu J, Zeng P. Abdomen CT findings in a COVID-19 patient with intestinal symptoms and possibly false negative RTPCR before initial discharge. Quant Imaging Med Surg 2020;10:1158-61. 